\title{
Tiroid Fonksiyon Bozukluğu Bulunan Hastalarda Erken Dönem Kardiyak Disfonksiyonu Belirlemede N-Terminal Pro-B-Tip Natriüretik Peptid
}

\author{
N-TerminalPro-B-Type Natriuretic Peptide For Detecting Early Cardiac \\ Dysfunction in Patients with Thyroid Dysfunction
}

\author{
Makbule Ulusoy, Şamil Gerek* , Namık Yiğit, Fatma Aylin Ayer, Yeşim Gürkan, \\ Hikmet Feyizoğlu, Macit Koldaş**, Mesut Ayer \\ Sağıık Bakanlığı Haseki Eğitim ve Araştırma Hastanesi, iç Hastalıkları Kliniği, Istanbul, Türkiye \\ *Sağ ılk Bakanlığı Kadirli Devlet Hastanesi, Dahiliye Kliniği, Osmaniye, Türkiye \\ **Sağlık Bakanlığı Haseki Eğitim ve Araştırma Hastanesi, Biokimya Kliniği, istanbul, Türkiye
}

\section{Özet}

Amaç: Bu çalışmanın amacı hipotiroidi ve hipertiroidi tanısı almış, ekokardiyografik ve klinik olarak herhangi bir kardiyak problemi bulunmayan hastalarda NT-proBNP düzeyinin erken dönem kardiyak disfonksiyonunun belirteci olarak kullanımını araştırmaktır.

Yöntem: Hastanemizin iç Hastalıkları polikliniklerine başvuran tiroid hastalığı konmuş 13'ü erkek, 40'ı kadın toplam 53 hasta ile 40 sağlıklı kontrol çalışmaya dahil edildi. Çalışmaya alınan hastaların daha öncesine ait bilinen bir hastalık öyküsü yoktu ve yeni tanı almış aşikar hipotiroidi ve hipertiroidi hastalarıydı. Hasta ve kontrol gruplarının kan örneklerinde rutin biyokimyasal parametrelere, tiroid fonksiyon testlerine ve NT-proBNP düzeylerine bakıldı, elektrokardiyogram çekildi ve ekokardiyografi yapıldı.

Bulgular: Çalışmaya alınan hastaların 28'inde hipotiroidi, $25^{\prime}$ inde hipertiroidi mevcuttu. Hipotiroid grubun yaş ortalaması daha yüksekti. Hipertiroidi ve hipotiroidili hasta grubunda NTproBNP ortalaması kontrol grubuna göre anlamlı derecede yüksekti ( $p=0.019$ ). Bu iki hasta grubu ayrı ayrı kontrol grubu ile karşılaştırıldığında NT-proBNP düzeyi hipotiroidili $(p=0.0096)$ ve hipertiroidili ( $p=0.0415$ ) hastalarda kontrol grubuna göre anlamlı olarak yüksek bulundu.

Sonuç: Artmış NT-proBNP düzeyi kalp yetersizliği ve koroner arter hastalığında kötü prognozu gösteren önemli bir belirteçtir. Bu nedenle artmış NT-proBNP düzeyi aşikar hipotiroidi ve hipertiroidisi olan hastalarda erken dönem kardiyak disfonksiyonu belirlemede değerli bir belirteç olabilir. (Haseki Tıp Bülteni 2013; 51: 102-6)

Anahtar Kelimeler: Hipertiroidi, hipotiroidi, kardiyak disfonksiyon, NT-proBNP

\begin{abstract}
Aim: The aim of this study was to investigate N-terminal probrain natriuretic peptide (NT-proBNP) as a marker of early cardiac dysfunction in patients with hypothyroidism or hyperthyroidism without any clinical and echocardiographic cardiac problem.
\end{abstract}

Methods: A total of 53 patients (13 male and 40 female), who were newly diagnosed with thyroid disease and 40 healthy controls who attended our internal medicine outpatient clinic, were included in the study. The patients had no history of any disease and, all of them were with newly diagnosed overt hypothyroidism or hyperthyroidism. Routine biochemical tests, and thyroid function tests were done and NT-proBNP levels were measured. Electrocardiograms and echocardiograms were performed.

Results: There were 28 patients with hypothyroidsm and 25 patients with hyperthyroidism in the study group. The mean age of hypothyroidism group was higher than that of hyperthyroidism group. The mean NT-proBNP levels were significantly higher in the patient group when compared to the control group $(p=0.019)$. When the two groups of patients were compared with the control group separately, the level of NT-proBNP was significantly higher in hypothyroidism group ( $p=0.0096)$ and hyperthyroidism group $(p=0.0415)$.

Conclusion: Elevated NT-proBNP levels are an important marker that suggests worse prognosis in heart failure and coronary artery disease. Elevated serum NT-proBNP levels might be a valuable marker to detect early cardiac dysfunction in patients with overt hypothyroidism and hyperthyroidism. (The Medical Bulletin of Haseki 2013; 51: 102-6)

Key Words: Hyperthyroidsim, hypothyroidism, cardiac dysfunction, NT-proBNP
Yazışma Adresi/Address for Correspondence: Makbule Ulusoy

Sağlık Bakanlığı Haseki Eğitim ve Araştırma Hastanesi, iç Hastalıkları Kliniği, i̇stanbul, Türkiye Tel.: +90 2126933638 E-posta: makulusoy@gmail.com

Geliş Tarihi/Received: 01 Şubat 2013 Kabul Tarihi/Accepted: 4 Mart 2013
Haseki Tıp Bülteni,

Galenos Yayınevi tarafından basılmıştır.

The Medical Bulletin of Haseki Training and Research Hospital, published by Galenos Publishing. 


\section{Giriş}

Tiroid hormonunun kalbi ve sistemik sirkülasyonu etkilediği yıllardan beri bilinmektedir. Tiroid hormonu oksijen tüketimini ve termogenezi arttırır, düşük yoğunluklu lipoprotein (LDL) kolesterolün yıkımını hızlandırır. Triiodotironin (T3) miyokardda miyozit kontraktilitesini arttırır. Kalbin ileti sisteminde sinoatrial düğümde depolarizasyon ve repolarizasyonu değiştirerek kalbi hızlandırır (1).

Aşikar hipertiroidizmde ventriküler hipertrofi, ventriküler disfonksiyon ve atrial fibrilasyon kardiyovasküler mortaliteyi arttırır. Bu hastalarda kardiyovasküler hastalık riski 1.7 artmıştır. Aşikar hipotiroidizm ise hiperkolesterolemi ve hipertansiyon gibi aterosklerozun risk faktörleri ile karakterizedir (2). Uzun süreli hipotiroidizmde sol ventrikül performansı da azalır. Bradikardi ve nabız basıncında daralma olur. QT intervalinin uzamasına bağlı ventriküler aritmiler gelişebilir. Hipertansiyon ve dislipidemi sonucu koroner arter hastalığının progresyonu artabilir. Ayrıca hipotiroidizm sistemik inflamasyon, hiperhomosistinemi, endotelyal disfonksiyon, hiperkoagülopati, fibrinoliziste bozulma ve trombosit anormalliklerine yol açabilir (3). Bu bağlamda tiroid hormonu hem direkt hem de indirekt olarak kardiyovasküler sistemi etkilemektedir.

Natriüretik peptidler kan basıncını, elektrolit dengesini ve sıvı volümünü düzenleyen bir hormon sınıfıdır (4). Bu peptidlerin ANP (atrial natriüretik peptid), BNP (B-tipi natriüretik peptid) ve CNP (C- tipi natriüretik peptid) olmak üzere üç tipi vardır (5). BNP'nin prekürsör peptidi olan proBNP 108 amino asit içeren öncü peptiddir ve miyositlerde salgı granüllerinde depolanır. Artan ventrikül duvarı gerilimi sonucu proteaz enzimi ile 32 amino asit içeren biyolojik olarak aktif olan BNP ile aktif olmayan N-terminal-proBNP (NT-proBNP)'ye bölünür (6).

Ventrikül duvar gerilimi arttığı zaman pro-BNP sağ ve sol ventrikülün her ikisinde de üretilir. Nörohormonal mekanizmayla damarların düz kas proliferasyonunda azalma, natriürez ve diürezde azalma ve miyokard fibrozunda azalma gibi etkiler yapar (7). BNP'nin ana kaynağı ventriküller olduğu için ventrikül bozukluklarının belirleyicisi olarak diğer natriüretiklere göre daha duyarlı ve özgül kabul edilmektedir (8).

NT-proBNP'nin yarılanma ömrü BNP'ye göre daha uzundur. NT-proBNP'nin yarılanma ömrü yaklaşık 2 saat iken, aktif bölüm olan BNP'ninki yaklaşık 22 dakikadır. Bu nedenle NT-proBNP'nin miktarının kanda tespiti daha kolaydır (9).

Hastaneye yatışın en sık sebeplerinden biri olan kalp yetersizliğinin erken tanı ve tedavisi mortalite ve morbiditeyi azaltır (10). Asemptomatik evrede ve kalp yetersizliğinin başlangıç evrelerinde BNP düzeyinin yükselmeye başlaması bu peptidin erken tanıda duyarlıığına işaret eder. Hastaların plazma BNP düzeyindeki artış ise kalp yetersizliğinin ciddiyeti ile korelasyon gösterir (11).

Koroner arter hastalığı olan hastalarda da artmış NTproBNP düzeyi diğer geleneksel ve yeni biyobelirteçlerle kıyaslandığında en iyi öngörücü prognoz göstergesi olarak düşünülmektedir (12).

$\mathrm{Bu}$ çalışmanın amacı herhangi bir kardiyak problemi olmayan aşikar hipotiroidi ve hipertiroidi hastalarında NTproBNP düzeyinin erken dönem kardiyak disfonksiyonun bir belirteci olarak kullanımını araştırmaktır.

\section{Gereç ve Yöntem}

Hastanemizin iç Hastalıkları polikliniklerine başvuran herhangi bir sistemik ve kardiyak hastalığı olmayan 13'ü erkek 40' ıadın olmak üzere tiroid hastalığı tanısını yeni almış toplam 53 hasta çalışmamıza dahil edildi. Kontrol grubu olarak da bilinen bir sistemik hastalığı olmayan ve ilaç kullanmayan 17'si erkek, 23'ü kadın toplam 40 sağlıklı birey alındı. Kontrol grubuna da hastalara yapılan tüm tetkikler yapıldı.

Tüm hastalarda sigara, koroner arter hastalığı, hiperlipidemi, hipertansiyon, obezite, diabetes mellitus, kronik renal yetmezlik ve kronik karaciğer hastalığı sorgulandı.

Fizik muayene sırasında tansiyon, nabız, boy ve kiloları ölçüldü. Kan basınçları en az beş dakika dinlenme sonrası sağ koldan sfingometre ile ölçüldü. Vücut ağırlığı ise hafif giyeceklerle, ayakkabısız olarak $0.1 \mathrm{~kg}$ hassasiyete sahip tartı ile ölçüldü.

Kan örnekleri ortalama 12-14 saatlik açıı sonrası sabah alındı. BUN, kreatinin, glukoz, elektrolitler, transaminazlar, $H D L$, $L D L$ ve VLDL kolesterol, trigliserid, LDH ile tam kan sayımı ve eritrosit sedimantasyon hızı araştııılı. Hormon parametrelerinden TSH, serbest T3 (FT3), serbest T4 (FT4), antitiroglobulin ve antitiroid peroksidaz değerleri de ölçüldü. Hastane biyokimya laboratuvar ölçümlerine göre TSH için 0.35- $4.94 \mathrm{mlU} / \mathrm{lt}$, FT3 için $1.71-3.71 \mathrm{pg} / \mathrm{ml}$ ve FT4 için 0.7-1.48 ng/dl değerleri normal aralık olarak kabul edildi. TSH değeri $10 \mathrm{mlU} / \mathrm{It}$ 'nin üzerinde olup FT3 $1.71 \mathrm{pg} / \mathrm{ml}$ ve FT4 $0.7 \mathrm{ng} / \mathrm{dl}$ altında olanlar aşikar hipotiroidi; TSH $0.35 \mathrm{mlU} / \mathrm{lt}$ altında olup FT3 $3.71 \mathrm{pg} / \mathrm{ml}$ ve FT4 1.48 ng/dl üzerinde olan hastalar aşikar hipertiroidi kabul edildi. Hastaların tümüne ayrıca elektrokardiyografi, ekokardiyografi ve tiroid ultrasonografisi yapıldı.

NT-proBNP düzeyleri için kan örnekleri EDTA'lı tüplere alınarak santrifüj edildi. Plazmadan ayrılarak $-20{ }^{\circ} \mathrm{C}^{\prime} \mathrm{de}$ saklandı. Örnekler NT-proBNP kiti ile Dade Behring marka Dimention Plus cihazında sandviç immunoassay yöntemi ile çalısııldı.

Biyokimyasal değerler Abbott 16.000 ci entegre sistemi ile Abbott orijinal kitleri kullanılarak, hormon ölçümleri ise Abbott Architech cihazı ile CMIA yöntemi ile çalışıldı. 
Verilerin istatiksel analizinde Statistical Package for Social Sciences (SPSS) programı kullanıldı. Parametrik veriler ortalama \pm standart sapma olarak, nonparametrik veriler ise \% olarak ifade edildi. Gruplar arasındaki sayısal verilerin karşılaştır ılması için "one-way ANOVA" testi, çoklu karşılaştırmalar için ise "post-hoc Tukey HSD" testi kullanıldı. Gruplar arasındaki oranların karşılaştııılması kikare testi ile yapıldı. İstatistiksel analizler yapılırken $p<0.05$ değeri istatistiksel olarak anlamlı kabul edildi.

\section{Bulgular}

Çalışma grubuna alınan 53 hastanın 13'ü (\%25) erkek, 40'ı (\%75) kadındı. Bu hastalardan 28'inde (\%53) hipotiroidi, $25^{\prime}$ inde (\%47) ise hipertiroidi mevcuttu. Kontrol grubundaki 40 hastanın 17'si (\%43) erkek, 23'ü (\%57) kadındı.

Hipotiroidik olanların 24'ü (\%86) kadın, 4'ü (\%14) erkek iken, hipertiroidisi olanların 16'sı (\%64) kadın, 9'u (\%36) erkekti. Hipotrioidi grubunda kadın oranı daha fazlaydı $(p=0.066)$.

Yaş ortalaması kontrol grubunda $39.03 \pm 12.37$ iken, hipotiroidik hastalarda $46.15 \pm 11.91$, hipertiroidik hastalarda ise $34.90 \pm 11.49$ idi. Hipotiroidi grubunun yaş ortalaması diğer iki gruba göre daha büyüktü ve istatistiksel olarak anlamlı idi $(p=0.001)$.

Tiroid disfonksiyonu olan hastaların NT-proBNP ortalaması kontrol grubuna göre daha yüksekti $(p=0.019)$ (Tablo 1).

Hipertiroidi ve hipotiroidili hastalar ayrı ayrı kontrol grubu ile karşılaştırılığında her iki hasta grubunun NTproBNP düzeyi kontrol grubuna göre istatistiksel olarak anlamlı derecede yüksek bulundu. Sırasıyla $p=0.0415$ ve $p=0.0096$ olarak saptandı.
Tiroid disfonksiyonu olan hastalarla kontrol grubu NTproBNP ortalamaları arasındaki fark istatistiksel olarak anlamlı idi ( $p=0.006)$ (Tablo 2).

Hasta ve kontrol grubuna yapılan ekokardiyografi değerlendirildiğinde gruplar arasında sol atrium çapı bakımından istatistiksel olarak anlamlı fark yoktu $(p=0.824)$. Ayrıca gruplar arasında sol ventrikül diastol sonu çapı bakımından da istatistiksel olarak anlamlı fark saptanmadı. $(p=0.383)$ (Tablo 1$)$.

\section{Tartışma}

Kardiyovasküler hastalıklar halen en sık mortalite sebepleri arasındadır. Bu nedenle bilinen kardiyak risklere ilaveten klinik kardiyak olay riskini işaret eden alternatif biyokimyasal belirteçler daha çok önem kazanmışır (13). Bir çok çalışmada tiroid stimülan hormon (TSH) seviyesindeki anormalliklerin kardiyak risk faktörü olarak değerlendirilebileceği gösterilmiştir $(14,15)$. Tiroid hormon seviyesindeki ciddi değişiklikler serum kolesterol seviyesini, kalp ritmini ve hızını, ventrikül fonksiyonunu, koroner arter hastalığı riskini ve sonuçta kardiyovasküler mortaliteyi etkilemektedir $(16,17)$.

Subklinik tiroid hastalıklarının tedavi edilmesi veya takip edilmesi konusunda net bir uzlaşı yoktur. Ama aşikar tiroid hastalıkları artmış kardiyovasküler hastalık riski taşır. Danimarka'da 50 yaş ve üstü sol ventrikül fonksiyonları normal olan 609 olgunun 5 yıl takibinin yapıldığı bir çalışmada TSH seviyeleri düştükçe, NTproBNP konsantrasyonlarının arttığı saptanmıştır. NTproBNP seviyelerinin TSH seviyesi ile ters orantılı olduğu gözlenmiş ve majör kardiovasküler olayların özellikle de inme insidansının subklinik hipertiroidili olgularda arttığı saptanmıştır (18).

Tablo 1. Tiroid disfonksiyonu olan grupla kontrol grubu NT-proBNP, sol atrium ve sol ventrikül diastol sonu çapı karşılaştırmaları

\begin{tabular}{|c|c|c|c|c|}
\hline Parametre & $\begin{array}{l}\text { Kontrol grubu } \\
\qquad(n=40) \\
\text { Ortalama } \pm S D\end{array}$ & $\begin{array}{l}\text { Hipotiroidi grubu } \\
\qquad(n=28) \\
\text { Ortalama } \pm S D\end{array}$ & $\begin{array}{l}\text { Hipertiroidi grubu } \\
\qquad(n=25) \\
\text { Ortalama } \pm \text { SD }\end{array}$ & p değeri \\
\hline NT-proBNP (pg/ml) & $20.07 \pm 18.75$ & $48.65 \pm 60.79$ & $42.69 \pm 48.20$ & 0.019 \\
\hline Sol atrium çapı (mm) & $3.070 \pm 0.536$ & $3.143 \pm 0.538$ & $3.068 \pm 0.481$ & 0.824 \\
\hline Sol ventrikül diastol sonu çapı (mm) & $4.45 \pm 0.37$ & $4.55 \pm 0.44$ & $4.40 \pm 0.36$ & 0.383 \\
\hline
\end{tabular}

Tablo 2. Tiroid disfonksiyonlu hastalarla kontrol grubu NT-proBNP ortalamaları arasındaki farkın değerlendirilmesi

\begin{tabular}{|c|c|c|c|}
\hline \multirow{2}{*}{ Parametre } & $\begin{array}{c}\text { Hasta grubu (n=53) } \\
\text { Ortalama } \pm \text { SD }\end{array}$ & $\begin{array}{c}\text { Kontrol grubu (n=40) } \\
\text { Ortalama } \pm \text { SD }\end{array}$ & p değeri \\
\hline NT-proBNP $(\mathrm{pg} / \mathrm{ml})$ & $45.72 \pm 54.51$ & $20.07 \pm 18.75$ & 0.006 \\
\hline
\end{tabular}


Başka bir çalışmada aşikar hipertiroidizmde kontrol grubuna göre BNP düzeyi 6 kat yüksek tespit edilmiştir (19). Bizim çalışmamızda da hipertiroidili hastaların NTproBNP düzeyi kontrol grubuna göre yüksekti.

Kalp yetersizliğinde hastalığın ağırlığı oranında dolaşımdaki BNP ve proBNP seviyeleri artar. Fakat aynı zamanda kardiyak aritmiler, ventriküler hipertrofi, miyokard iskemisi, pulmoner emboli, akut ve kronik kor pulmonale, böbrek yetmezliği, anemi, hipertiroidizm ve sepsis gibi hastalık durumlarında da yükselebilir (20). Graves hastalığı tanısı konmuş hastalarla yapılan bir çalışmada kontrol altındaki hipertiroidi hastalarında da serum NTproBNP düzeyinin yükseldiği saptanmıştir. Anormal tiroid hormon seviyeler i kadar endotelyal disfonksiyonun da bu durumdan sorumlu olabileceği düşünülmüştür (21).

Schulz ve arkadaşlarının yaptığı bir çalışmada 17'si aşikar 4'ü subklinik hipotiroid ve 13'ü aşikar 6'sı subklinik hipertiroid hastada tedavi öncesi ve sonrası NT-proBNP düzeyi ölçülmüş, NT-proBNP düzeyinin hipertiroidi hastalarında hipotiroidi hastalarına göre 4 kat yüksek olduğu saptanmıştır. Serum NT-proBNP düzeyi tiroid hormon düzeyi ile korele bulunmuştur. Tedavi sonrası ise hipertiroidi grubunda NT-proBNP düzeyinde azalma, hipotiroidi grubunda artma saptanmıştır (22). Bizim yaptığımız çalışmada ise hipertroidi ve hipotiroidi hasta grubunun NTproBNP ortalaması kontrol grubunun ortalamasına göre daha yüksekti. Ayrıca hipertirodili ve hipotiroidili hastalar ayrı ayrı kontrol grubu ile karşılaştııılığında da her iki hasta grubunda NT-proBNP düzeyi kontrol grubuna göre istatistiksel olarak anlamlı derecede yüksek bulundu.

Çeşitli çalışmalarda hipertiroidili hastaların ortalama serum NT-proBNP düzeyi hem kontrol grubundan hem de hipotiroidi hasta grubundan daha yüksek bulunmuştur. Hipotirodili hastalarla kontrol grubunun NT-proBNP düzeyleri arasında anlamlı farklılık bulunmamış, serum NTproBNP düzeyi ile tiroid hormon düzeyi arasında pozitif bir korelasyon saptanmışıı $(23,24)$.

Bizim çalışmamızda ise hipertiroidi hastaları gibi hipotiroidi hastalarında da NT-proBNP artışı saptandı. Hipotiroidi hastalarındaki NT-proBNP artışı literatürle uyumlu değildi. Bu durum çalışmamıza nisbeten az sayıda hasta alınmasından ve kadın cinsiyetin daha fazla olmasından kaynaklanmış olabilir. Ayrıca hipotiroid hastaların yaş ortalamasının diğer iki gruba göre daha yüksek olması da NT-proBNP düzeyini etkilemiş olabilir.

Hipertiroidizm geleneksel ekokardiografi ile tespit edilemeyen kardiyak disfonksiyonlara neden olabilir ve bu değişiklikler NT-proBNP'yi yükseltebilir (23). Yaptığımız çalışmada tüm hastalara ekokardiyografi yapıldı. Ejeksiyon fraksiyonu, sol ventrikül diastol sonu basıncı ve sol atrium volüm indeksi de dahil olmak üzere çeşitli parametreler ölçüldü. Hipotiroidi, hipertiroidi ve kontrol grubu kendi aralarında karşılaştıııldığında bu parametreler açısından istatistiksel olarak anlamlı fark bulunmadı.

Serum NT-proBNP düzeyi kardiyovasküler hastalıkların çeşitli formlarında ve bunlara bağlı mortalitede güçlü bir öngörücü olarak görev yapar. Atrial fibrilasyonu olan hastalarda da atrial distansiyon sonucu NT-proBNP düzeyi yüksek saptanır. $(25,26)$ NT-proBNP seviyesi vasküler hastalığın varlığı veya tanısından çok ağırlığını göstermede daha iyi bir gösterge olabilir. Artmış serum NT-proBNP düzeyi ağır kardiyovasküler hastalığı olan ve hızlı progresyon gösteren hastaları saptamada yararlı olabilir (27).

Tiroid hormonları hücresel mRNA düzeyini arttırarak atrial natriüretik peptid (ANP) ve BNP sentezini doğrudan etkiler. Bu nedenle kardiyak hemodinamiden bağımsız olarak tiroid hormonları ANP ve BNP düzeylerinde artışa neden olabilir $(28,29)$.

Bir çok çalışmada hipotiroidik hastaların NT-proBNP düzeyleri ile kontroller arasında istatistiksel olarak anlamlı fark bulunmamıştır. Bizim yaptığımız çalışmada ise hem hipertiroidik hem de hipotiroidik hastalarda NT-proBNP ortalamaları kontrol grubuna göre daha yüksekti (hipotiroidi ve kontrol grubu NT-proBNP karşılaşıırması $p=0.0096$; hipertiroidi ve kontrol grubu NT-proBNP karşılaştırması $p=0.0415$ ). Bu durum hem hipertiroidi hem de hipotiroidi hastalarında erken dönem kardiyak disfonksiyon riskini belirlemede NT-proBNP'nin önemli bir belirteç olabileceğini düşündürmektedir.

Plazma NT-proBNP konsantrasyonu yaşla artar ve erkeklere göre kadınlarda daha yüksektir (30). Ayrıca renal yetmezlik, diabetes mellitus, anemi, beta bloker, ACE inhibitörü ve anjiotensin reseptör blokerleri gibi bir çok faktör NT-proBNP düzeyini etkileyebilir $(31,32)$.

Bizim çalışmamızdaki sonuçların literatürle paralel olmamasının nedeni hasta sayımızın az olması, hipotiroidi grubunda kadın cinsiyetinin fazlalı̆̆ ve yaş ortalamasının yüksek olmasından kaynaklanabilir. Tüm hastalar yeni tanı aşikar hipotiroidi ve hipertiroidi hastaları olup hastaların hipotiroidi ve hipertiroidi dönemi süreleri bilinmemektedir. Bu da çalışmamızı kısıtlayan önemli nedenlerdendir. Çünkü kardiyak disfonksiyon gelişmesi hastaların hastalık süreleri ile koreledir.

Bu nedenle daha geniş hasta serileri içeren randomize yeni çalışmalarla tiroid disfonksiyonu ile NT-proBNP arasındaki ilişki daha doğru şekilde değerlendirilebilir.

\section{Kaynaklar}

1. Ladenson P, Kim M. Tiroid. In: Goldman L, Ausiella D. Cecil Medicine. 23 th ed. Philadelphia: Saunders; 2011:1698-704.

2. Dörr M, Völzke H. Cardiovascular morbidity and mortality in thyroid dysfunction. Minerva Endocrinol 2005;30:199-216.

3. Cappola AR, Ladenson PW. Hypothyroidism and atherosclerosis. J Clin Endocrinol Metab 2003;88:2438-44. 
4. Han B, Hasin Y. Cardiovascular effects of natriuretic peptides and their interrelation with endothelin-1. Cardiovascular Drugs Ther 2003;17:41-52.

5. Lainscak M, von Haehling S, Anker SD. Natriuretic peptides and other biomarkers in chronic heart failure: from BNP, NTproBNP, and MR-proANP to routine biochemical markers. Int J Cardiol 2009;132:303-11.

6. Liang $F, O^{\prime}$ Rear $J$, Schellenberger $U$, et al. Evidence for functional heterogeneity of circulating B-type natriuretic peptide. J Am Coll Cardiol 2007;49:1071-8.

7. Pu DR, Chiong JR, Zhou QC Clinical applications of N-terminal pro B-type natriuretic peptide in heart failure and other cardiovascular diseases. Heart Fail Rev 2010;15:293-304.

8. Daniels LB, Maisel AS. Natriuretic peptides. J Am Coll Cardiol 2007; 50:2357-68.

9. Ozturk TC, Unluer E, Denizbasi A, Guneysel O, Onur O. Can NTproBNP be used as a criterion for heart failure hospitalization in emergency room? J Res Med Sci 2011;16:1564-71.

10. Heart Failure Society of America, Lindenfeld J, Albert NM, et al. HFSA 2010 Comprehensive Heart Failure Practice Guideline. J Card Fail 2010;16:1-194.

11. Aspromonte N, Valle R, Peacock WF, Vanderheyden M, Maisel A. Inpatient monitoring and prognostic importance of B-type natriuretic peptide. Congest Heart Fail 2008;14(Suppl 1):30-4.

12. Bode $E$, Wuppinger $T$, Bode $T$, et al.. Risk stratification in stable coronary artery disease: superiority of $\mathrm{N}$-terminal pro B-type natriuretic peptide over high-sensitivity C-reactive protein, gamma-glutamyl transferase, and traditional risk factors. Coron Artery Dis 2012;23:91-7.

13. Cappola AR, Fried LP, Arnold AM, et al. Thyroid status, cardiovascular risk, and mortality in older adults. JAMA 2006;295:1033-41.

14. Imaizumi M, Akahoshi M, Ichimaru S, et al.. Risk for ischemic heart disease and all-cause mortality in subclinical hypothyroidism. J Clin Endocrinol Metab 2004;89:3365-70.

15. Walsh JP, Bremner AP, Bulsara MK, et al. Subclinical thyroid dysfunction as a risk factor for cardiovascular disease. Arch Intern med 2005;165:2467-72.

16. Parle JV, Maisonneuve P, Sheppard MC, Boyle P, Franklyn JA. Prediction of all-cause and cardiovascular mortality in elderly people from one low serum thyrotropin result: a 10-year cohort study. Lancet 2001;358:861-5.

17. Cappola AR, Ladenson PW. Hypothyroidism and atherosclerosis. J Clin Endocrinol Metab 2003;88:2438-44.

18. Schultz M, Kistorp C, Raymond I, et al. Cardiovascular events in thyroid disease: a population based, prospective study. Horm Metab Res 2011; 43:653-9.

19. Wei T, Zeng C, Tian Y, Chen Q, Wang L. B-type natriuretic peptide in patients with clinical hyperthyroidism. J Endocrinol Invest 2005;28:8-11.
20. Omland T, Hagve TA. Natriuretic peptides: physiologic and analytic considerations. Heart Fail Clin 2009;5:471-87.

21. Gu LQ, Zhao L, Zhu W, et al. Relationships between serum levels of thyroid hormones and serum concentrations of asymmetric dimethylarginine (ADMA) and N-terminal-pro-Btype natriuretic peptide (NT-proBNP) in patients with Graves' disease. Endocrine 2011;39:266-71.

22. Schultz M, Faber J, Kistorp C, et al. N-terminal-pro-B-type natriuretic peptide (NT-pro-BNP) in different thyroid function states. Clin Endocrinol 2004;60:54-9.

23. Arikan S, Tuzcu A, Gokalp D, Bahceci M, Danis R. Hyperthyroidism may affect serum $\mathrm{N}$-terminal pro-Btype natriuretic peptide levels independently of cardiac dysfunction. Clin Endocrinol (Oxf) 2007;67:202-7.

24. Ozmen B, Ozmen D, Parildar Z, Mutaf I, Bayindir O. Serum $\mathrm{N}$-terminal-pro-B-type natriuretic peptide (NT-pro-BNP) levels in hyperthyroidism and hypothyroidism. Endoc Res 2007;32:1-8.

25. Struthers AD, Davies J. B B-type natriuretic peptide: a simple new test to identify coronary artery disease. QJM 2005;98;765-9.

26. Linssen GC, Bakker SJ, Voors AA, et al. N-terminal proB-type natriuretic peptide is an independent predictor of cardiovascular morbidity and mortality in the general population. Eur Heart J 2010;31:120-7.

27. Nilsson K, Gustafson L, Hultberg B. The use of N-terminal pro-brain natriuretic Peptide to evaluate vascular disease in elderly patients with mental illness. Dement Geriatr Cogn Dis Extra 2012;2:10-18.

28. Liang F, Webb P, Marimuthu A, Zhang S, Gardner DG. Triiodothyronine increases brain natriuretic peptide (BNP) gene transcription and amplifies endothelin-dependent BNP gene transcription and hypertrophy in neonatal rat ventricular myocytes. J Biol Chem 2003;278:15073-83.

29. Rodríguez E, García AM, Foyo E, Amato D, Paniagua R. Role of thyroid hormones on the synthesis and release of atrial natriuretic peptide in rats with acute renal failure. Nephron Exp Nephrol 2003;95:24-9.

30. Raymond I, Groenning BA, Hildebrandt PR, et al. The influence of age, sex and other variables on the plasma level of $\mathrm{N}$-terminal pro brain natriuretic peptide in a large sample of the general population. Heart 2003;89:745-51.

31. Troughton RW, Richards AM, Yandle TG, Frampton CM, Nicholls MG. The effects of medications on circulating levels of cardiac natriuretic peptides. Ann Med 2007;39:242-60.

32. Cui $H$, Huo G, Liu L, et al. Association of cardiac and renal function with extreme $\mathrm{N}$-terminal fragment pro-B-type natriuretic peptide levels in elderly patients. BMC Cardiovasc Disord 2012; 12:57. 